\title{
Spring frost effects on 30 sweet cherries varieties grown in North Italy
}

\author{
Roversi, A. ${ }^{1}$, Pattori, E. ${ }^{2}$, Malvicini, G.L. ${ }^{1}$ \& Sbaruffati, S. ${ }^{3}$ \\ ${ }^{1}$ Institute of Fruit Growing, Faculty of Agriculture, Catholic University S.C., 29100 Piacenza - Italy \\ ${ }^{2}$ Institute of Plant Pathology, Faculty of Agriculture, Catholic University S.C. 29100 Piacenza - Italy \\ ${ }^{3}$ Plant Protection Service, Regione Emilia Romagna, 29100 Piacenza - Italy
}

\begin{abstract}
Summary: After a spring frost occurred in second half of March 2008, with temperatures below $0^{\circ} \mathrm{C}$ for 8 days consecutively and an absolute minimum of $-5.5^{\circ} \mathrm{C}$, a lot of observations have been made on the sweet cherry flowers damages. In three different orchards "Italian palmetta" trained on grassing ground soil, the percentage of the flowers killed by frost, was detected and recorded considering the different genotypes and flowers height from the ground. Furthermore, in one orchard only it was possible to find relationship between flowering stage and frost damage. The results clearly confirm our previous works about the highest mortality of the flower in the upper part $(>1.50 \mathrm{~m})$ of the canopy and in the full bloom open flowers. So, in this area, the easiness of agronomic operations, like pruning and, especially, fruit harvest, due to the crown proximity to the ground, is cancelled by the frequency of spring frost.
\end{abstract}

Key words: flowers frost damages, sweet cherry, flowering stage

\section{Introduction}

In the Piacenza district, the cherry cultivation was made in a traditional way with big dimension trees and crowns over 3-4 meters from the ground. In the last 20 years, the cultivation was renewed with the introduction of new varieties and the generalized use of "palmetta" training system, the latter in order to facilitate cultural practices, especially fruit harvesting, because the bearing branches are near to the ground.

In the cherry growing area of Piacenza district, in the last 25 years of $20^{\text {th }}$ century, the plants are "Italian palmetta" trained to facilitate the cultural practices especially harvest. The occurrence of the spring frost during sweet cherry flowering in this area, gave our Institute the opportunity to check the effect of this spring frost. These events happened in 1995 (Roversi, Ughini, 1995), in 2002 (Roversi, Rossi, 2003 a) and 2003 (Roversi, Rossi, 2003 b).

All these researches have been made directly in field conditions where, of course, the situation of plant age, rootstocks, soil management, kind of bearing branch and genotypes were very far from an ideal experimental field in which all these variables could be under control. However, in general, the results of these researches clearly demonstrate how the "Italian palmetta" training system can be dangerous. In fact, in the last 45 years, in the considered area, the spring frost occurred one time every $2 / 3$ year. Again the spring frost damages involve especially the flowers in the lower part of the canopy and are related to flowers opening phase. In the last $10-15$ years, some sweet cherry growers of the Piacenza district used to insure their orchard against climatic adversity like winter and spring frost, and hail. Unfortunately, the insurance companies as well as the growers don't well know the sensitivity of different sweet cherry varieties to these adversities.

In 2008, a severe spring frost occurred and this has given us the opportunity to supply growers and insurance companies with new information about the varieties sensibility to frost and to confirm our previous results or not.

\section{Materials and methods}

\section{Climatic conditions}

In the considered area the temperature trend is usually recorded by the Plant Protection Service and for these studies we consider the month of March 2008.

\section{Orchards}

We made observations on 3 different orchards, contiguous and neighbouring, located within a $1500 \mathrm{~m}$. radius from the temperature recorded in Villanova sull'Arda (Piacenza district).

In the orchard 1, plants of 18 varieties, 7 years old, were grafted on Colt and spaced $5 \times 4 \mathrm{~m}$.

In orchard 2, plants of 5 years old, spaced $4.80 \times 3 \mathrm{~m}$, were grafted on 2 different rootstocks that are Colt for 12 varieties and Gisela 5 for the others.

In orchard 3, the varieties were 13, 11 years old, spaced $5 \times 5$ and grafted on Colt. All the orchards were at "Italian palmetta" trained, on grassing ground soil. 
The observation were made on 20 plants at random in all the considered orchards, within one week after the 2008 spring frost.

For each plant, 2 bearing branches were chosen both at a lower level and above 1.50 meters from the ground, and this for both sides (right and left) of the row. For each of the 4 bearing branches, all the flowers of the spur (may bouquet) selected just in the middle of each branch, were dissected, to check the mortality for all the flowers by recording the number of them killed by frost.

Only for the orchard 3, as in this case we have been able to record the flowers damages within before 48 hours from the event, the flowers opening stage was also correctly recorded to define its effect on flowers mortality. The data were statistically analyzed by " $t$ " test to evidence the differences in the flowers mortality related to their different height from the soil and the effect of flowers phenological stage.

\section{Results}

\section{Climatic trend}

As we can see in the fig. 1, in the considered area the temperature was below $0{ }^{\circ} \mathrm{C}$ for 8 days; in particular a minimum of $-5.5^{\circ} \mathrm{C}$ occurred on March $6^{\text {th }}$ but this date was very far from the cherry blooming beginning. On the contrary, the anthesis had already started in the week from 19 to 26 March in which the temperature was always below $0{ }^{\circ} \mathrm{C}$. Especially in the night of 24, 25, 26, the temperature was very close to or lower than $-5{ }^{\circ} \mathrm{C}$. Unfortunately, these temperatures were preceded by some days of temperatures above $10{ }^{\circ} \mathrm{C}$ and up to $15^{\circ} \mathrm{C}$ that stimulated the anthesis rate. So, the flowers damages increased.

\section{Average mortality related to different orchards and varieties}

As shown in tables 1, 2 and 3, the mortality due to the spring frost was very variable among varieties and for the same variety among orchards.

In particular, in the orchard 1 the mortality ranged from $.00 \%$ for Canada Giant, to $91.2 \%$ for Symphony. The mortality lower than $50 \%$, was observed for Celeste, Big Lory, Early Lory, Giorgia and Sunburst, while Black Star and Summit flowers were killed at more than $80 \%$.

In the orchard 2, we have to consider separately the varieties grafted on 2 different rootstocks that are 12 on Colt and 7 on Gisela 5. For the varieties grafted on Colt, the mortality percentage ranged from $1.9 \%$ for Canada Giant, up to $62.3 \%$ for Early B.G. The varieties with a mortality over $50 \%$ were Cordia, Ferrovia, Black Star and Early B.G.

For the varieties grafted on Gisela 5, the average mortality seems to be higher than the varieties grafted on Colt. Unfortunately, we couldn't make any comparison because we haven't the same varieties grafted on both rootstocks. The minimum observed value was $7.8 \%$ for Simcoe and the maximum $79.0 \%$ for Early Lory.

It is noticeable and strange that in this orchard Big Lory, Early Lory, Lapins, Sweet Hearth, Ferrovia and Black Star were the most damaged compared to the previous one. However, it must be observed that the rootstocks and the age of these 2 orchards are different.

In the orchard 3 the lower mortality level (7.9\%) of flower was observed in B. Moreau.

For the varieties Van, Prime Giant and Adriana, the mortality was lower than $50 \%$.

For the other varieties, the mortality was very high up to percentages at 90 or more, with a value $(97.3 \%)$ near the mortality of all the flowers (see tab. 3).

Unfortunately, the varieties common to the 3 orchards were only Canada Giant, Lapins and Sweet Hearth while 9 varieties were common to orchard 1 and 2 , so it's really difficult to evidence genotype effect, as hidden by some other variables as plant age, rootstock, cultivation management etc. However, the mortality percentage of some varieties is of the same order of magnitude. In orchard 1 and 2, these varieties were Celeste, Giorgia and Ferrovia. On the contrary, in the orchard 1 and 3, the varieties with a flower mortality of similar order of magnitude were Lapins, Sweet Hearth, B. Burlat, Samba and Sonata.

The mortality of Canada Giant $(75.0 \%)$ is very higher in orchard 3 if compared with the one of orchard 1 and 2, with the values at $.0 \%$ and $1.9 \%$, respectively. On the contrary, the mortality of Bigarreau Moreau in orchard $1(74.5 \%)$ is higher if compared to the percentage $(7.9 \%$ ) observed in orchard 3 . Again, the mortality of Big Lory and Early Lory observed in orchard 2 are more than the double of the percentage observed in orchard 1.

All these data are very difficult to explain because the mortality records were made in a real orchard situation and not in an experimental one. However, the data could be helpful when the spring frost happens and nobody has an idea of flowers sensibility of different varieties, in order to estimate the damage suitable to be insured.

\section{Average mortality as related to the flowers height from the ground}

The effects of flowers height from the ground on their mortality is shown in tables 4, 5 and 6. As expected and showed in previous works (Roversi, Ughini, 1995; Roversi, Rossi, 2003 a; Roversi, Rossi, 2003 b) the flowers located at a level below 1.50 metres from the ground were more damaged by spring frost. Even if not always significant, the mortality of the flowers located in the lower part of palmetta was always higher vs. the one of the flowers in the upper part of palmetta. At this regard, in orchard 1, the average mortality of the flowers located above $1.50 \mathrm{~m}$. was $71.0 \%$ and $50.1 \%$ in flowers located over this height level and the difference was highly significant.

The difference between the mortality of flowers located over $1.50 \mathrm{~m}$., is often not significant but the trend is really 
clear for all the cultivars with the exception of Celeste and Giorgia in orchard 1.

This demonstrates that the cherry growers don't consider the risk of spring frost damage and prefer plant training system with crown near the soil that facilitates harvesting operations.

Obviously, the reduction of frost damages would be very useful. For this purpose climate-control irrigation over crown to delay flowering time or to protect directly the flowers could be applied, as demonstrated by Roversi and Rossi (2003).

\section{Average mortality as related to flowers phenological stage}

As above-mentioned in Materials and Methods, only in the orchard 3 we have had the opportunity to check the phenological stage of the damaged flowers within 48 hours after the frost event.

The related data are shown in tab. 7, which proves that the percentage of mortality is higher for the full open flowers. This confirms the results of our previous work (Roversi, Ughini, 1995; Roversi, Rossi, 2003 a; Roversi, Rossi, 2003 b.) carried out in the same district, after the spring frost in the years 1995, 2002 and 2003.

Table 1. Average of flowers percentage destroyed by spring frost, in orchard 1

\begin{tabular}{|l|c|c|}
\hline Varieties & Value\% & Duncan's test \\
\hline Canada Giant & .0 & A \\
\hline Celeste & 22.5 & AB \\
\hline Big Lory & 31.7 & B \\
\hline Early Lory & 35.0 & BC \\
\hline Giorgia & 35.0 & BC \\
\hline Sunburst & 36.3 & BC \\
\hline Blaze star & 52.9 & BCD \\
\hline Lapins & 65.0 & CDE \\
\hline Sweet heart & 70.8 & DE \\
\hline Samba & 71.7 & DE \\
\hline B. Moreau & 74.5 & DE \\
\hline Sonata & 74.9 & DE \\
\hline Flamengo & 77.1 & DE \\
\hline Ferrovia & 77.5 & DE \\
\hline B. Burlat & 78.7 & DE \\
\hline Black Star & 83.3 & DE \\
\hline Summit & 88.8 & E \\
\hline Synphony & 91.2 & E \\
\hline
\end{tabular}

\section{Discussion}

The flowers mortality due to spring frost results very variable among orchards and a clear effect of genotype was not evidenced because the same varieties (e.g. Big Lory and Early Lory) show results depending on the orchard only. In a previous work, too, (Roversi, Rossi, 2003 b) it was demonstrated that the spring frost damage in 2 different years
Table 2. Average of flowers percentage destroyed by spring frost, in orchard 2

\begin{tabular}{|c|c|c|c|}
\hline $\begin{array}{l}\mathrm{R} \\
\mathrm{t} \\
\mathrm{s}\end{array}$ & Varieties & Value $\%$ & Duncan's test \\
\hline \multirow{4}{*}{$\mathrm{C}$} & Canada Giant & 1.9 & A \\
\hline & Satin & 5.5 & $\mathrm{AB}$ \\
\hline & Van & 14.6 & $\mathrm{AB}$ \\
\hline & Celeste & 30.9 & $\mathrm{BC}$ \\
\hline \multirow[t]{2}{*}{$\mathrm{O}$} & Lapins & 32.5 & $\mathrm{BC}$ \\
\hline & Giorgia & 33.3 & $\mathrm{BC}$ \\
\hline $\mathrm{L}$ & Sweet heart & 44.5 & $\mathrm{CD}$ \\
\hline \multirow{5}{*}{$\mathrm{T}$} & Grace Star & 46.2 & $\mathrm{CD}$ \\
\hline & Kordia & 50.8 & $\mathrm{CD}$ \\
\hline & Ferrovia & 58.3 & $\mathrm{CD}$ \\
\hline & Black Star & 56.7 & $\mathrm{CD}$ \\
\hline & Early B.G. & 62.3 & $\mathrm{D}$ \\
\hline G & Simcoe & 7.7 & $\mathrm{~A}$ \\
\hline I & Lory Bloom & 19.2 & $\mathrm{AB}$ \\
\hline S & Lory Strong & 29.5 & $\mathrm{ABC}$ \\
\hline $\mathrm{E}$ & Late Lory & 46.6 & $\mathrm{BCD}$ \\
\hline $\mathrm{L}$ & Summit & 55.6 & $\mathrm{CDE}$ \\
\hline A & Big Lory & 67.5 & $\mathrm{E}$ \\
\hline 5 & Early Lory & 79.0 & $\mathrm{E}$ \\
\hline
\end{tabular}

Table 3. Average of flowers percentage destroyed by spring frost, in orchard 3

\begin{tabular}{|l|c|c|}
\hline Varieties & Value\% & Duncan's test \\
\hline B. Moreau & 7.9 & A \\
\hline Van & 34.2 & B \\
\hline Prime Giant & 37.5 & B \\
\hline Adriana & 43.5 & BC \\
\hline Lapins & 55.6 & BCD \\
\hline Sumini & 61.7 & BCDE \\
\hline Kordia & 67.5 & CDEF \\
\hline Canada Giant & 75.0 & DEFG \\
\hline B. Burlat & 84.2 & DEFG \\
\hline Sweet Heart & 82.5 & DEFG \\
\hline Samba & 90.0 & EFG \\
\hline Sonata & 92.1 & FG \\
\hline Early B.G. & 97.3 & G \\
\hline
\end{tabular}

for the same 11 genotypes, didn't show any relationship. However, the genotype-effect has been surely hidden or "masked" by a lot of other effects like plant age, rootstock and flowers opening stage.

In this work, it was possible to observe that the absolute minimum temperature of $-5^{\circ} \mathrm{C}$ caused a very high flowers damage related to some variables as variety, flowers height from the ground and their flowering stage. The mortality was generally very high with averages of 39.1 in orchard 2 and 63.8 in orchard 3 . The highest mortality percentage in the full bloom open flowers could mean that the varieties with an early blooming could be more damaged (Fisher et al., 1987). 
Table 4. Average of flowers percentage destroyed by spring frost, in orchard 1 as related to flowers height from the ground

\begin{tabular}{|c|c|c|c|}
\hline \multirow{2}{*}{ Varieties } & \multicolumn{2}{|c|}{ Height from the ground } & \multirow{2}{*}{ significance $(p)$} \\
\hline & $<1.50 \mathrm{~m}$ & $>1.50 \mathrm{~m}$ & \\
\hline Canada Giant & - & - & - \\
\hline Celeste & 15.0 & 30.0 & .297 \\
\hline Big Lory & 40.0 & 23.3 & .250 \\
\hline Early Lory & 55.6 & 26.2 & .013 \\
\hline Giorgia & 35.0 & 35.0 & .999 \\
\hline Sunburst & 55.2 & 20.0 & .021 \\
\hline Blaze star & 71.7 & 34.2 & .032 \\
\hline Lapins & 95.6 & 34.4 & .010 \\
\hline Sweet heart & 85.0 & 56.7 & .124 \\
\hline Samba & 85.0 & 58.3 & .080 \\
\hline B. Moreau & 100.0 & 57.5 & .039 \\
\hline Sonata & 86.7 & 33.3 & .007 \\
\hline Flamengo & 86.7 & 67.5 & .099 \\
\hline Ferrovia & 81.7 & 73.3 & .482 \\
\hline B. Burlat & 83.3 & 74.2 & .473 \\
\hline Black Star & 95.0 & 71.7 & .103 \\
\hline Summit & 97.5 & 80.0 & .021 \\
\hline Synphony & 100.0 & 82.4 & .034 \\
\hline Average & 71.0 & 50.1 & .000 \\
\hline
\end{tabular}

Table 5. Average of flowers percentage destroyed by spring frost, in orchard 2 as related to rootstock and to flowers height from the ground

\begin{tabular}{|c|c|c|c|c|}
\hline \multirow{2}{*}{$\begin{array}{l}\mathrm{R} \\
\mathrm{t} \\
\mathrm{s}\end{array}$} & \multirow{2}{*}{ Varieties } & \multicolumn{2}{|c|}{ Height from the ground } & \multirow{2}{*}{ significance $(\mathrm{p})$} \\
\hline & & $<1.50 \mathrm{~m}$ & $>1.50 \mathrm{~m}$ & \\
\hline \multirow{4}{*}{$\mathrm{C}$} & Canada Giant & 3.3 & .4 & .343 \\
\hline & Satin & 8.5 & 2.5 & .390 \\
\hline & Van & 24.0 & 5.2 & .063 \\
\hline & Celeste & 32.6 & 29.3 & .846 \\
\hline \multirow[t]{2}{*}{$\mathrm{O}$} & Lapins & 34.6 & 30.3 & .809 \\
\hline & Giorgia & 36.7 & 30.0 & .589 \\
\hline \multirow[t]{2}{*}{$\mathrm{L}$} & Sweet heart & 59.2 & 29.7 & .014 \\
\hline & Grace Star & 72.2 & 20.0 & .001 \\
\hline \multirow[t]{4}{*}{$\mathrm{T}$} & Cordia & 75.8 & 25.9 & .001 \\
\hline & Ferrovia & 73.3 & 43.4 & .057 \\
\hline & Black Star & 59.8 & 53.5 & .423 \\
\hline & Early B.G. & 72.5 & 52.1 & .057 \\
\hline G & Simcoe & 15.3 & .0 & .017 \\
\hline I & Lory Bloom & 22.0 & 16.5 & .655 \\
\hline $\mathrm{S}$ & Lory Strong & 33.3 & 25.7 & .689 \\
\hline $\mathrm{E}$ & Late Lory & 47.3 & 45.9 & .933 \\
\hline $\mathrm{L}$ & Summit & 72.7 & 38.4 & .099 \\
\hline A & Big Lory & 66.7 & 68.3 & .917 \\
\hline 5 & Early Lory & 100.0 & 58.0 & .025 \\
\hline
\end{tabular}

In the same district during the spring-frost of 1994, 2002 and 2003, a lot of observations have been made on different varieties, which often were the same as the present work.

At the end of March 2002 and in the first week of April 2003 , the average flowers mortality ranged around $70 \%$ with
Table 6. Average of flowers percentage destroyed by spring frost, in orchard 3 as related to flowers height from the ground

\begin{tabular}{|l|c|c|c|}
\hline \multirow{2}{*}{ Varieties } & \multicolumn{2}{|c|}{ Height from the ground } & \multirow{2}{*}{ significance (p) } \\
\cline { 2 - 3 } & $<1.50 \mathrm{~m}$ & $>1.50 \mathrm{~m}$ & \\
\hline Adriana & 43.8 & 43.2 & .964 \\
\hline B. Burlat & 93.3 & 75.0 & .243 \\
\hline B. Moreau & 13.3 & 2.50 & .169 \\
\hline Canada Giant & 95.0 & 55.0 & .015 \\
\hline Early BiGi & 100.0 & 94.6 & .182 \\
\hline Kordia & 80.0 & 55.0 & .133 \\
\hline Lapins & 60.2. & 50.1 & .233 \\
\hline Prime Giant & 45.0 & 30.0 & .476 \\
\hline Samba & 91.2 & 88.8 & .995 \\
\hline Sonata & 99.8 & 84.4 & .041 \\
\hline Sumini & 72.5 & 50.8 & .174 \\
\hline Sweet Heart & 98.5 & 66.5 & .013 \\
\hline Van & 48.3 & 20.0 & .091 \\
\hline Average & $\mathbf{7 2 . 3 8}$ & $\mathbf{5 5 . 0 7}$ & .020 \\
\hline
\end{tabular}

Table 7. Average of flowers percentage destroyed by spring frost, in orchard 3 as related to their phonological stage

\begin{tabular}{|c|c|c|c|}
\hline Varieties & 90 & (3) & \\
\hline Adriana & $3.7 \mathrm{~A}$ & $60.6 \quad \mathrm{~B}$ & $66.2 \mathrm{~B}$ \\
\hline B. Burlat & $72.5 \mathrm{a}$ & $82.0 \mathrm{a}$ & $98.0 \mathrm{a}$ \\
\hline B. Moreau & $4.8 \mathrm{a}$ & $8.6 \mathrm{ab}$ & $10.3 \quad b$ \\
\hline Canada Giant & $57.2 \mathrm{a}$ & $80.7 \mathrm{ab}$ & $87.2 \mathrm{~b}$ \\
\hline Early BiGi & $95.0 \mathrm{a}$ & $97.0 \mathrm{a}$ & $100.0 \mathrm{a}$ \\
\hline Kordia & $43.0 \mathrm{a}$ & $74.5 \quad b$ & $85.0 \quad b$ \\
\hline Lapins & 39.6 a & $62.7 \mathrm{ab}$ & $64.5 \quad b$ \\
\hline Prime Giant & $27.0 \mathrm{a}$ & $36.8 \mathrm{a}$ & 48.6 a \\
\hline Samba & $71.5 \mathrm{a}$ & $98.5 \quad b$ & $100.0 \quad b$ \\
\hline Sonata & $77.5 \mathrm{a}$ & $98.9 \quad b$ & $99.9 \quad b$ \\
\hline Sumini & $44.3 \mathrm{a}$ & $67.2 \mathrm{ab}$ & $73.7 \quad b$ \\
\hline Sweet Heart & $71.6 \mathrm{~A}$ & $75.8 \mathrm{AB}$ & $100.0 \quad \mathrm{~B}$ \\
\hline Van & $27.5 \mathrm{a}$ & $34.3 \mathrm{a}$ & 40.9 a \\
\hline Average & $48.86 a$ & $67.20 a$ & $74.95 a$ \\
\hline
\end{tabular}

an absolute minumum temperature of $-5.00^{\circ} \mathrm{C}$ and $-6.25^{\circ} \mathrm{C}$, respectively (Roversi, Rossi, 2003 a, 2003 b).

Unfortunately, due especially to different plant age, rootstocks and orchards, comparison couldn't be correctly made. However, the strong and often significant effect of flowers height from the soil level and of the stage of flowering, were plenty confirmed.

The results of this work and of the previous ones bring into serious doubt the opportunity to adopt the "Italian palmetta" in this area.

In fact, the easiness of agronomic operations, like pruning and, especially, fruit harvest, due to the crown proximity to the ground, is cancelled by the frequency (a time every 2,3 years) of spring frost which destroys a large number of flowers in many varieties. 


\section{References}

Fisher, M., Salzer, J. \& Kock, H.J. (1987): Frostvertränglichkeit der Obstarten. IV. Mitteilung: BlÜtenfrostschaden-serhebungen an Süsskirschen. Archiv. Gartenbau, 35 (4): 155-168.

Roversi, A., (1980): Alcuni aspetti della biologia fiorale del ciliegio dolce con particolare riguardo all'influenza del clima. Atti convegno: La coltura del ciliegio dolce: indirizzi e prospettive. Scodovacca di Cervignano del Friuli (UD), 12 luglio, pp. 107-114.
Roversi, A. \& Unghini V., (1995): Danni da abbassamenti termici in pre-fioritura sul ciliegio dolce. Italus Hortus, 5-6: 49-57.

Roversi, A. \& Rossi, E., (2003 a): Mortalità delle gemme a fiore del ciliegio dolce a seguito di brinate tardive. Frutticoltura, 6: 61-66.

Roversi, A. \& Rossi, E., (2003 b): Mortalità da brinate tardive su gemme a fiore di ciliegio. L'Informatore Agrario, 25: 27-30. 